\title{
"But When do I do Critical Literacy?" Perspectives for Designing Critical Literacy Activities in EFL Classrooms
}

\section{"Mas quando eu faço letramento crítico?" Perspectivas para a elaboração de atividades de letramento crítico em salas de aula de língua inglesa}

Érika Amâncio Caetano*

*Universidade Federal de Minas Gerais (UFMG), Belo Horizonte, Minas Gerais/ Brasil erikasoares.ingles@gmail.com

https://orcid.org/0000-0002-5147-7728

\begin{abstract}
This paper aims to present a set of principles for the design of critically grounded activities for English classes in regular school settings. Such principles are based on the pillars of critical literacy according to renowned linguists and scholars of the area, as well as pre-established criteria proposed by Richards (2001) and adapted by Rashidi (2011) for critical-pedagogical practice. A brief contextualization will be presented, as well as theoretical foundations for the organization of such criteria. Following this moment, two practical examples, based on the Brazilian context, will be presented in order to demonstrate the applicability of these theories in language classes at regular schools. The directions hereby proposed are aimed at guiding ELT teachers' reflections as they try to implement critically based activities in their classrooms.
\end{abstract}

KEYWORDS: Critical literacy; principles; activities based on critical literacy; English language teaching (ELT); regular schools.

RESUMO: O presente artigo tem como objetivo apresentar um conjunto de princípios para a elaboração de atividades criticamente embasadas para aulas de língua inglesa na educação básica. Tais princípios são baseados nos pilares do letramento crítico de acordo com renomados linguistas e pesquisadores da área e em critérios pré-estabelecidos propostos por Richards (2001) e adaptados por Rashidi (2011) para a prática pedagógica crítica. Uma breve contextualização será apresentada, assim como a fundamentação pedagógica para a organização de tais critérios. A seguir, dois exemplos práticos, levando-se em conta o contexto brasileiro, serão apresentados para demonstrar a aplicabilidade das teorias do letramento crítico em aulas de língua estrangeira na escola regular. Os direcionamentos aqui propostos destinam-se a guiar reflexões de professores 
de língua inglesa na elaboração de atividades criticamente embasadas em suas salas de aula.

PALAVRAS-CHAVE: Letramento crítico; princípios para a elaboração de atividades baseadas no letramento crítico; aulas de língua inglesa; escola regular.

\section{Introduction}

This article constitutes a cutout of my MA thesis, defended in 2014 at the School of Languages and Linguistics of the Federal University of Minas Gerais. At the time, the objective was to design activities based on the theories of Critical Literacy (CL) and to observe the possible impact of their application in an English language classroom of a regular school in Belo Horizonte, Minas Gerais, Brazil. To this end, I was guided by the pillars of CL common to different scholars of the area and by pre-established principles and criteria for the design of critically grounded activities so as to organize a set of principles which could guide myself and other teachers during this process. When teaching both undergraduate and graduate programs, the realization that students had quite a hard time attempting to apply CL perspectives in their everyday practice made my desire to use and share those principles even stronger.

This way, due to the great deal of help provided by such principles during my process of designing critically grounded activities both during my MA thesis (SOARES, 2014) and my PhD dissertation (CAETANO, 2017), I decided to share in this article theoretical and practical information that could contribute to the applicability of the CL perspectives in language classrooms in Brazil and in other contexts. A brief contextualization of CL in English classes will be presented so as to provide the readers with a greater understanding of the path taken towards the organization of the principles for designing CL-based activities. Next, some practical examples will be shown and discussed. It is important to emphasize that this is only a small step within the multiple possibilities of comprehending CL and applying its perspectives in language classrooms. It is expected, however, that this paper will bring theoretical references and practical ideas that will help teachers better understand CL perspectives and become better prepared to design their own activities. 


\section{CL in the teaching of EFL}

The teaching of English as a foreign language (EFL) in Brazil dates back from 1809. It is understood, for example, that although structuralism has given way to the communicative approach, with a focus on the student and in the teaching of functional English, the approach adopted in the basic Education network, for a number of reasons, is reduced to instrumental teaching of this language and disregards the local learning context and the subjects involved in this process.

When considering a local context of learning and subjects involved in the teaching and learning of a foreign language, the social changes that have occurred in the last years (CARMO, 2010) must be considered, as well as the way they have significantly affected the profile of regular school students. These social changes, associated with the inability of methods and approaches to explain the process of English as a foreign language (EFL) learning as a whole (LARSEN-FREEMAN, 2000; RICHARDS RODGERS, 2001), have, in the 90s, led to research such as Kumaravadivelu's (1994, 1999), which advocated for locally oriented pedagogical practices, in order to encompass the students' voices, their desires, expectations and active participation in their learning process.

Hall (1995 apud OKAZAKI, 2005) reiterates this perspective and argues that the pedagogy and the theory governing language teaching "should cater for the socio-historical and political forces that reside both in the meanings of the resources and the social identities of those who seek to use them" (p. 175). The political character of ELT is perceived here, given that the language can be seen as an instrument for the development of critical consciousness and a sense of student participation as a citizen and a member of a community.

According to Jorge (2012),

[r]econceptualizing approaches to teaching English as a foreign language in Brazil constitutes a significant political change with regard to "regular" schools, since it is considered that teaching a language should be seen as much more than Only offer students a tool for communication. The English language is also seen as a tool to promote criticality and reflection. (p. 842)

This is also the perspective fomented by the Brazilian Curricular Guidelines for High School (OCEM). These guidelines firstly mention 
that the purposes of secondary education are "the improvement of the student as a human being, their ethical education, the development of their intellectual autonomy and their critical thinking, their preparation for the world of work and the development of competencies to continue their learning" (BRASIL, 2006, p. 7). With regard to the teaching of foreign languages, the OCEM propose that the discipline constitutes a means for "the formation of individuals, which includes the development of social consciousness, creativity, an open mind for new knowledge, finally, a reform in the way of thinking and seeing the world" (BRASIL, 2006, p. 90). We conclude from these proposals the intention of developing the students' citizenship, in order to situate them about the position they occupy in the society in which they live.

Seeking to provide a contextualization of CL in the teaching of EFL in a theoretical perspective, let us see below a comparative analysis between CL, Communicative Approach (CA) and Post-method Pedagogy, concepts which present, despite differences, important intersections.

\section{Critical literacy, communicative approach and post-method pedagogy - brief comparative analysis}

We have seen in the previous section that CL, in agreement with the OCEM (BRAZIL, 2006), represents an attempt to develop the students' critical consciousness to make them active citizens in their community. In order to situate CL in ELT more significantly, this section presents a chronological description of the ELT process from the communicative approach perspective. This description will culminate in the post-method theory by Kumaravadivelu (1994), followed by a brief epistemological analysis of these three perspectives - CA, CL and post-method - for ELT.

The 70s marked the beginning of significant changes in ELT, with the involvement of researchers and professionals in the field in search for a more meaningful teaching approach for students and teachers. Up to the 60 s, language was seen as a system of rules, and it was up to the learners to internalize such rules by means of paths imposed by the teacher or by the educational institution. The primary objective of the learner in this context was to infer the linguistic principles of the target language. The construction of meaning, in turn, ended up assuming a secondary role (RICHARDS; ROGERS, 2001). 
Thus, during the 70s, linguists and researchers observed that language needed to be understood as a means of expression, communication and production of meaning. The realization that language could be analyzed, described and taught as a system focused on meaning, together with the perception that the needs of students involve the social use of the target language, generated what is now understood as the Communicative Approach. According to Widdows and Voller (1991), EFL students do not like classes controlled by the teacher, without their opinions being taken into consideration. According to the authors, for students' needs to be addressed, changes are needed both in the course content and in the types of courses to be offered, in addition to a teacher education process that focuses on such needs.

Thus, in the early $70 \mathrm{~s}$, a communicative feature was attributed to the teaching of English (RICHARDS; ROGERS, 2001). The Communicative approach (CA), therefore, was characterized by the social use of the language, which was an important step in the English language teaching and learning processes. In this context, the student becomes the center of the process and starts to use English in interactive contexts, in order to express him/herself and construct meaning from the target language (VALÉRIO; MATTOS, 2018).

Despite the importance of the CA in the sense of prioritizing the socio-functional character of the language and the student as an individual, some linguists pointed out the imperialistic and market-based character of this approach - in their perspective, English is seen as a symbol of power and status and, as a result, cultural and ideological aspects seem to be imposed through coursebooks designed with the purpose of perpetuating power relations (KUMARAVADIVELU, 2012). According to Kumaravadivelu (2012), the post-colonial perspective of English language education ultimately relates the learning of this language "to the creation of jobs and wealth, benefiting the economy of language-speaking countries through a worldwide industry of ELT (English language Teaching)" (p. 7). Thus, with the demands of the market, there comes the need to negotiate meanings in the target language, and to use this language in a variety of pre-established contexts, prioritizing some of them to the detriment of others.

Although the effectiveness of CA in a variety of ELT contexts is undeniable, some researchers tend to believe that in CA-based classes, knowledge, rather than built collaboratively, is transmitted to the student. 
Like other traditional approaches, the communicative approach uses the transmission of pre-selected structures to the student, creating situations "close to reality", in which critical reflection or integration of the student's worldview may sometimes be disregarded. According to Kumaravadivelu (2012), the main problem of language teaching approaches is the limitation of the teacher's role to that of a conduit, which "passes along easily digested portions of knowledge" (p. 8). This scenario may lead to the consequent teacher-student hierarchy and also the reinforcement of the imperialistic character of language teaching approaches, which could hinder the collaborative construction of knowledge.

Therefore, there has been a need for a perspective that addresses the teaching of English as socially, culturally and historically situated, that is, context sensitive (KUMARAVADIVELU, 2012). This perspective was called post-method (KUMARAVADIVELU, 2003; 2006) and, as the name already says, it proposes the teaching of English which goes beyond the concept of method, in order to consider the local context and the subjects involved in this process, as well as its peculiarities.

According to Pennycook (1989), the concept of method reflects a worldview linked to the interests of the dominant class, indicating that the top-down structure of the method does not consider the multiplicity of learners, their needs and the various teaching/learning contexts in which they are inserted. Kumaravadivelu (2012) reiterates this perspective, claiming that such conception comprises students as "a common client with common goals" (p. 10). The post-method condition is thus an effort by Kumaravadivelu to exceed the limited conception of method, integrating the teaching of languages to three principles - the particularity of learners and contexts, the practicality of classes, or approximation between theory and practice, and the possibility of collaborative construction of knowledge through questioning and critical reflection. Such principles are fundamental to understanding the post-method condition.

Among the three principles postulated by Kumaravadivelu (2012), the principle of possibility is especially related to the epistemology of critical pedagogy, since it represents a rupture with the teaching programs that

(...) merely transmit a body of knowledge and content; instead, it favors those who generate sociopolitical consciousness among all participants so that they can form and transform their personal and social identities. (KUMARAVADIVELU, 2012, p. 15) 
It is possible to infer that the conception of CL would be intimately linked to the post-method condition, constituting a practical application of the principle of possibility aiming at the social transformation of both teachers and students. Thus, by realizing that the three principles adopted by Kumaravadivelu (2012) relate directly to teacher education, the need for preparing these professionals to challenge the conventional teaching strategies and integrate into their pedagogical practice elements that go far beyond the language itself or the content of the material becomes evident. Since teachers understand the implications of their true role in the classroom, they can use CL theories to promote discussions that lead to autonomy, political consciousness and active participation of their learners. In order to do so, in the critical perspective, the teacher is " $(. .$.$) recognizing$ the rich resources that students and families possess, what these students bring to school and how what they bring is or is not valued, recognized and built on the curriculum, in classrooms and in school environments (...)" (HAWKINS, 2011, p. 107).

Once questions concerning the conception of CL have been clarified through the analysis of competing terms, we now move to the process of creating a set of criteria for the design of critically grounded activities.

\section{Principles for the design of critically grounded activities: theoretical background}

Soares (2009) claims that literacy deals primarily with reading practices. Thus, when we talk about CL, it is necessary to understand that the activities developed within this perspective should encompass the reading and discussion of different texts ${ }^{1}$ so that, through them, it is possible to provide students with opportunities for critical reflection and transformation in the way they see the world and interact with their reality. Let us now see some examples of activities designed within this perspective.

In her work on evaluation, Duboc (2007) suggests three modifications to activities previously designed in light of CL theories, using themes such as meals, family and celebrities to promote discussions that go far beyond the

\footnotetext{
${ }^{1}$ According to the New Literacy studies, a text is anything which can be interpreted, that is, from which meaning making is possible. For instance, a text can be printed, digital, imagetic or oral (MATTOS, 2015).
} 
predictably traditional learning practices. According to the author, through the analysis of seemingly harmless images and texts, it is possible to propose strategies which exceed a simplistic comprehension of the text and elicit the reconstruction of meanings as well as critical-reflective positioning of the students in relation to their own reality, this constituting the basis of student empowerment.

Mattos (2012) also discusses critically grounded activities designed by teachers from the public education sector in Belo Horizonte to show the feasibility of the implementation of CL in ELT. Two examples presented in the author's work are the activities of teachers Dora and Maurício. Dora worked with the Nokia website to propose an activity whose ultimate goal was to prepare students to write a letter of complaint about a mobile phone purchased online, which was defective. According to Dora's own reflections, the pre-reading activities and the preparation for the letter created space for discussions on citizenship and enabled students to understand how to exercise their citizenship through a letter of complaint and use that knowledge outside the classroom. What differs this type of activity from a CA based lesson is the focus on students' citizenship and social engagement rather than only the fulfillment of a communicative function.

Maurício's activity focused on dengue, a common health problem in the community where he worked. He used a popular Brazilian comic strip to discuss the problem with the students, who researched the disease at home and then produced posters explaining the causes of dengue and showing ways to avoid it. The posters were posted on the walls of the school in order to alert the community about the problem. It is possible to perceive that both activities seek to promote the exercise of citizenship by the students, since they warn of situations that permeate their universe and represent a source of practical knowledge to be used in their daily life.

Even though these activities constituted an initial reference on how to use CL in English classes, I felt the need for establishing some criteria for the presence of CL in the activities I later designed in my MA thesis (SOARES, 2014) and my PhD dissertation (CAETANO, 2017). This way, in order to substantiate the set of criteria proposed for design of the activities developed in Soares (2014) and Caetano (2017), it is necessary to briefly contextualize our current moment, in order to show the role of CL in ELT.

Multiculturalism, emphasized by globalization and pointed out by Kalantzis and Cope (2006) and Kubota (2004), is perhaps the most 
important premise for the implementation of critical pedagogy in the educational context of today. The relations of domination, the hegemonies of power, the reproduction of privileges and the oppression must find in the classroom - space for awareness, struggle, questioning and social transformation, mainly because it is more than clear that historical and cultural diversity occupies a significant place in the geopolitical scene nowadays. What should be clear, according to Canagarajah (2005), is that globalization and multiculturalism per se are not characterized as transforming elements. Conversely, globalization can simply "reproduce the interests of the status quo" (p. 8). According to the author, although the Internet has "democratized social relations" in order to enable the manifestation of local cultures,

(...) we have to engage critically with postmodern conditions to create a space for local knowledge in terms of unempowered communities. There is work to be done in order to develop transformative pedagogies that would lead to more egalitarian relations in society and in education. (CANAGARAJAH, 2005, p. 9)

Rashidi (2011) warns about the need to combat the famous "banking education" - from Freire's banking metaphor -, also called acquisition metaphor, a process of transmitting knowledge in which the student's mind would be an empty receptacle where the teacher, knowledge keeper, would pour knowledge; the student then becomes the holder of this knowledge, which is compared to a material good. He argues that knowledge has a social function, and that, instead of constituting a passive learning process with individual enrichment of the student, the learning of a foreign language must be based on reflection, collaborative construction of knowledge and a sense of change and benefit. According to the author, an education that points out problems demands the insertion of questions that provoke thought in the classroom. Jorge (2012) reiterates such need, and emphasizes that, according to the OCEM, EFL teachers must address CL in the planning of classes, in the preparation of materials and in all their methodological choices, through the exploration of relevant themes such as citizenship, diversity, equality, social justice and values, among others.

However, while acknowledging the need for critically grounded materials, little has been done about it. According to Rashidi (2011), 
$[\ldots]$ as materials are generally considered the main resources in language learning programs, considerably little has been done with regard to the development of materials in the light of critical pedagogy and the whole area is practically undeveloped (p. 251).

Considering the prevailing pedagogical practices in ELT, the "false innocence" pointed out by Rashidi (2011) is clearly perceived in the design of materials, since the teaching of the 'language of the colonizer' is already a controversial theme per se. According to the author, the content of the materials available for teaching English as a foreign language is not consistent with the social reality of which the language is part. He cites Brown (1990) and Rinvolucri (1999) to show that these materials are made targeting the "Westernized adult" and that such themes do not encompass "the dark side of life" (p. 252), becoming - perhaps purposely - sources of knowledge mechanization and unsound discussions. Canagarajah (1999) reinforces this idea, claiming that, in an ELT context in which materials, curriculum and pedagogical practices are developed by Anglo-American communities, local differences between cultures and school realities are not accounted for, which ultimately makes classroom activities inappropriate, irrelevant and distant from students.

As we consider that materials are mostly the main source of content regarding language teaching, it is possible to conclude that they tend to conform to the ideology disseminated by the pedagogical practice. Thus, in the case of critical education, the materials to be used in the classroom should aim to educate the learner about their socio-political context and instigate them to fight against the status quo, seeking for transformation at both local and global levels simultaneously (NORTON; TOOHEY, 2004 apud RASHIDI, 2011).

Thinking of a set of materials which could contemplate questions concerning not only the local reality of the students, but also the representation of the world that surrounds them, Rashidi (2011) uses Richards' proposal (2001) to suggest more materials consistent with the critical perspective. Richards (2001) points out five factors for the design of materials: factors related to the program, the content, the pedagogical practice (or educational process), the teacher and the students (RASHIDI, 2011). Some researchers have adapted these factors in order to delimit the scope of each one. Thus, the following is the unfolding of the five factors proposed by Richards (2001) in Rashidi (2011). 


\section{Program Factors}

A. purpose: related to the overall objective of the program

B. objectives: related to the actual results of the program

\section{Content factors}

A. definition of content: related to the definition of themes used in materials

B. content Source: related to content selection source

C. content disposition: related to the content sequence

\section{Pedagogical factors}

A. the process of education: related to the method of knowledge and education in materials

B. the resort of the culture of origin: related to the position of local cultures in ELT materials

\section{Factors related to the teacher}

A. the role of the teacher: related to the role that the material has for the teacher

B. Teacher's expectations: related to the supposed expectations that the teacher takes to the classroom when using the materials

\section{Learner-related factors}

A. the role of the student: related to the role that the material has for the student

B. expectations of the learner: related to the supposed expectations that the student takes to the classroom when using the materials

It is important to emphasize that, in order to delimit the scope of the activities from this study and guide the reader, we will call them CL activities. Besides incorporating the factors proposed by Richards (2001 apud RASHIDI, 2011), they also follow the criteria below for the presence of CL:

I. “(...) A philosophy or approach to education that considers how education can empower individuals with the tools to understand and criticize the world, aiming to promote social justice" (JORGE, 2012, p. 10).

II. “(...) Teachers begin to see students as whole individuals, (...) begin to recognize (...) what students bring to classes and how what students bring is and is not valued, recognized and approached in the curriculum, in the classroom and in the school environment" (HAWKINS, 2011, p. 107).

III. “(...) Critical literacy goes far beyond what is understood as critical reading, which reflects more 'processes of logical thinking characteristic of the scientific process' (HARRIS; HODGES, 1995, p. 50). In critical 
literacy, readers see beyond the situation to examine it in a more complex way. Reading from a critical perspective requires readers to analyze and evaluate texts (...), significantly read and question their origin and purpose, and act through the representation of alternative perspectives. The goal is for readers to become textual critics in everyday life - to understand sources of information from a critical perspective as naturally as they comprehend the aesthetic and efferent perspectives" (McLAUGHLIN; DeVOOGD, 2004, p. 23).

In addition to the criteria described above, CL activities should also comprise the principles by Lewison, Flint and Van Sluys (2002 apud McLaughlin; DEVOOGD, 2004, p. 17-18), based on a bibliographic review of thirty years of literature produced about CL:

- Understanding of the text to obtain different perspectives;

- Analysis of the multiple points of view in a text, whether they are explicitly represented or not;

- Focus on socio-political issues, in order to think about the power relations between individuals;

- Action and promotion of social justice, through reflection and attitudes that foster changes in the inequalities that permeate our society.

This set of principles will be shown in the next section, along with some practical examples. Two activities developed in Soares (2014) and Caetano (2017) will be presented in order to offer the reader a concrete view of how such principles can be used in the process of designing CL activities.

\section{Practical Examples - Samples oriented by the principles for the design of CL Activities}

In this section, practical examples showing the applicability of the principles in EFL activities will be presented, as well as a brief analysis of the contribution of these activities for promoting CL in English lessons at regular schools. The two samples of activities hereby presented were designed during my MA and PhD research (SOARES, 2014; CAETANO, 2017). 
In Soares (2014) three activities were designed for a junior high school class from a public school in Belo Horizonte. In Caetano (2017) the activities were designed for two junior high school groups from a private school in the same city. In both scenarios, the activities were conceived based on an initial questionnaire which students answered about their English experience, their likes, dislikes and expectations concerning the language and the classes at their schools.

The background for the activities consisted of two moments Brazil was going through - the protests in 2013 and the Olympic games in 2016 - as well as demands which emerged from the initial questionnaires concerning their preferences and expectations. A correlation between such events and the contents of the coursebook was also established, in order to preserve the linguistic objectives established by the schools for each term. Thus, the factors proposed by Richards (2001 apud RASHIDI, 2011), the criteria for the presence of CL based on a set of ideas from well-known authors and, finally, the principles of CL by Lewison, Flint and Van Sluys (2002 apud MCLAUGHLIN; DEVOOGD, 2004) were used. All the activities proposed in Soares (2014) and Caetano (2017) were designed in light of these factors, criteria and principles.

Based on the proposed principles, the activities encompassed a set of actions which aimed to promote the autonomy and critical thinking of students, presenting themes pertinent to their reality. The content of the activities was based on questionnaires about students' preferences concerning English and the coursebook adopted by the institutions in which both studies took place. The principles conceived for the design of CL activities were adopted. The activities were developed observing each of the criteria from the set, in order to substantiate each of them.

The following is a brief description of two of the activities developed in Soares (2014) and Caetano (2017). The first activity is fully available in Soares (2014) and was based on the principles for CL activities, observed in $\operatorname{table}^{2} 1$.

\footnotetext{
${ }^{2}$ The table format was chosen in order to make the steps followed in the design process of the activity clear for the reader. It does not convey the conception of a framework or model, once the theories of CL are opposite to such perspective.
} 
TABLE 1 - CL principles Activity 1

\begin{tabular}{|l|}
\hline \multicolumn{1}{|c|}{$\begin{array}{l}\text { Principles for designing activities based } \\
\text { on CL }\end{array}$} \\
\hline $\begin{array}{l}\text { 1. Factors for designing materials within the } \\
\text { critical perspective (RICHARDS, } 2001 \text { apud } \\
\text { RASHIDI, 2011) }\end{array}$ \\
\hline
\end{tabular}

Program factors

A. purpose: related to the overall objective of the program.

B. objectives: related to the actual results/specific objectives of the program.

\section{Content factors}

A. definition of content: related to the definition of themes used in materials

B. content Source: related to content selection source

C. content disposition: related to the content sequence

\section{Pedagogical factors}

A. the process of education: related to the method of knowledge and education in materials

B. the resort of the culture of origin: related to the position of local cultures in ELT materials

\section{Factors related to teacher}

A. the role of the teacher: related to the role that the material plays for the teacher

B. Teacher's expectations: related to the supposed expectations that the teacher takes to the classroom when using the materials

\section{Factors related to the learner}

A. the role of the student: related to the role that the material plays for the student

B. expectations of the learner: related to the alleged expectations that the student takes to the room when using the materials
Traces of inclusion of principle in Activity 1

A. The program demanded the use of the Present Continuous (PC) and the introduction of the cartoon genre at the end of the second stage of the school year, and the activity promoted a review of the PC along with a comparison between cartoons and comic strips.

B. The activity is in agreement with the set of specific objectives from the program, especially regarding the reading strategies such as activation of previous knowledge, analysis of verbal and non-factual information and discussion on the intention of the author of the texts.

A. The activity was in accordance with the coursebook (CB), which presented the theme Peace activists.

B. A link was established between the previous unit, which worked with comics and the Present Continuous, and the beginning of the unit on Peace activists.

C. Although the activity represents a review of the previously given content, it is not sequenced within the CB.

A. The activity involved the same reading strategies taught by the participant teacher in other activities.

B. The chosen cartoons covered locally situated problems - the protests in Brazil in June and July of 2013.

A. The activity was reviewed by the participant teacher and was taught by the teacher herself, so as not to alter aspects related to her practice and to the dynamics in the classroom.

B. The activity was proposed to the participant teacher and accepted for being in conformity with the objectives established in the course plan, among them "to develop critical awareness about the English language in the student".

A. The activity considered the interaction of the student with the material, in order to instigate its participation.

B. The theme "protests in Brazil" was chosen because of the countless absences of students from class in a day that coincided with a protest in the city. In the following class, the students confirmed that they had been absent to participate in the protests. 


\section{Criteria for the presence of $\mathrm{CL}$}

I. “(...) A philosophy or approach to education that considers how education can empower individuals with the tools to understand and criticize the world, aiming to promote social justice” (JORGE, 2012, p. 10).

II. “(...) Teachers begin to see students as individuals in their entirety, (...) begin to recognize (...) what students bring to classes and how what students bring is and is not valued, recognized and approached in the curriculum, in the classroom and in the school environment" (HAWKINS, 2011, p. 107).

III. “(...) In CL, readers see beyond the situation to examine it in a more complex way. Reading from a critical perspective requires readers to analyze and evaluate texts (...), significantly read and question their origin and purpose, and act through the representation of alternative perspectives" (McLAUGHLIN; DeVOOGD, 2004, p. 23).

The cartoons about the protests in Brazil aimed to foster a discussion on political and social issues that permeate the students' lives; moreover, they enabled reflections upon the legitimacy of the manifestations and their consequent role as participants.

With this activity, the students' contribution to the discussion of the topic was sought through the acknowledgement of their experiences and opinions. It was expressed by the collaborative construction of knowledge, so that each individual report enriched the collective discourse.

The words in English in the activity were accompanied by images to facilitate readers' comprehension. This strategy allowed them to read the texts (both imagetic and written) in a way that goes beyond the literal or superficial reading of the text. By identifying the purposes underlying such texts, the students reflect upon the current structure and consequently act in favor of a more equitable political, economic and social structure.

With regard to action, real action follows the discussions brought up in class. The product is the students' own engagement within their community, since the context for the protests was thoroughly explored. The discussions culminated in a general understanding of their role as citizens, so as to provide them with purpose for socially transforming their current situation.
3. Principles of CL by Lewison, Flint e Van Sluys (2002 apud McLAUGHLIN; DeVOOGD, 2004, p. 17-18)

Understanding the text to obtain different perspectives

The use of cartoons seeks to obtain different readings and views on the same texts on the part of the students.

Analysis of multiple viewpoints in a text, whether they are explicitly represented or not

The access of all students to the set of cartoons allows each group to make a different reading of each cartoon, and the discussions create opportunities for students to be exposed to different points of view.

Focus on socio-political issues, in order to think about the power relations between individuals

The topic of cartoons - protests in Brazil - was used for this purpose.

If we think of action through reflection, this activity fosters discussions - and possibly attitudes - on the current problems of our country, considering issues such as income distribution, corruption and the need for equal opportunities for all.
Action and promotion of social justice through reflection and attitudes that foster changes in the inequalities that permeate our society

\begin{tabular}{|l|} 
\\
\hline $\begin{array}{l}\text { The use of cartoons seeks to obtain different readings } \\
\text { and views on the same texts on the part of the students. }\end{array}$ \\
$\begin{array}{l}\text { The access of all students to the set of cartoons allows } \\
\text { each group to make a different reading of each cartoon, } \\
\text { and the discussions create opportunities for students to be } \\
\text { exposed to different points of view. }\end{array}$ \\
$\begin{array}{l}\text { The topic of cartoons - protests in Brazil - was used for } \\
\text { this purpose. }\end{array}$ \\
$\begin{array}{l}\text { If we think of action through reflection, this activity } \\
\text { fosters discussions - and possibly attitudes - on the } \\
\text { current problems of our country, considering issues such } \\
\text { as income distribution, corruption and the need for equal } \\
\text { opportunities for all. }\end{array}$ \\
\hline
\end{tabular}

Below is a sample showing part of the student`s worksheet for this activity. $^{3}$

${ }^{3}$ The full activity, as well as the design process, is available in Soares (2014). 
FIGURE 1 - Activity 1 - Student's worksheet

\begin{tabular}{|c|}
\hline ACTIVIIY 1: Charges wbre o protesto \\
\hline 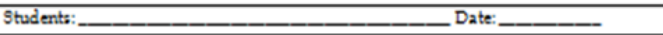 \\
\hline OBJETTOOS DA ALLA \\
\hline 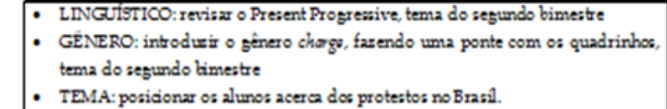 \\
\hline Warm-up: \\
\hline How do you say chargo in English? \\
\hline What are carbons for? (what are they used for?) \\
\hline What' s the difference betw een carbons and conries? \\
\hline Look at the cartoon below I \\
\hline mmiamorimsonomscombr \\
\hline * Do you resogrise the symbols in the picture? What do they represent? \\
\hline * What is happening in the picture? What is the cartoon criticining? \\
\hline
\end{tabular}

The second example is available in Caetano (2017). In this research, which portrayed an autoetnographic perspective, I decided to work with three mini-projects, which were part of a sequence. Below there is a brief description of the second mini-project developed in the study.

\section{MINI-PROJECT 2: The 10 Commandments}

CONTEXTUALIZATION: Activity based on the Ten Commandments associated with the different roles that students occupy in society. During the month of September (2016), we worked with unit 7 of the coursebook, involving technology at the service of mankind, tasks (chores) and the modal verbs should/must/mustn't/don't have to. I gave them the Ten Commandments to explore the modal verbs within the perspective of obligations and/or suggestions, and after a discussion 
of the individual duties based on these commandments, students were asked to create the Ten Commandments related to each role they occupy in society - friend, brother/sister, child, student, neighbor, citizen, boyfriend, using the vocabulary presented in the classroom. They should make a poster and in the following class introduce themselves to the English class, reporting lessons learned from the experience.

TABLE 2 - CL Principles Mini-Project 2

\begin{tabular}{|c|c|}
\hline $\begin{array}{l}\text { Principles for designing } \\
\text { Activities based on the CL }\end{array}$ & $\begin{array}{c}\text { Traces of inclusion of the } \\
\text { Principle in Activity }\end{array}$ \\
\hline \multicolumn{2}{|l|}{$\begin{array}{l}\text { 1. Factors for designing materials within the critical } \\
\text { perspective (RICHARDS, } 2001 \text { apud RASHIDI, 2011) }\end{array}$} \\
\hline $\begin{array}{l}\text { Program factors } \\
\text { A. purpose: related to the overall objective of the program } \\
\text { B. objectives: related to the actual results/specific objectives } \\
\text { of the program }\end{array}$ & $\begin{array}{l}\text { Task in line with the criteria of promotion of } \\
\text { criticality, autonomy, social interaction with the } \\
\text { written text and approximation of students to } \\
\text { their reality. }\end{array}$ \\
\hline $\begin{array}{l}\text { Content factors } \\
\text { A. definition of content: related to the definition of themes } \\
\text { used in materials } \\
\text { B. content Source: related to content selection source } \\
\text { C. content disposition: related to the content sequence }\end{array}$ & $\begin{array}{l}\text { Activity based on the content provided in CB } \\
\text { (modal verbs and vocabulary related to individual } \\
\text { duties - Ten Commandments), related to the } \\
\text { linguistic content and communicative functions } \\
\text { arranged in unit } 7 \text { of the book, following the } \\
\text { planning established for the school stage. }\end{array}$ \\
\hline $\begin{array}{l}\text { Pedagogical factors } \\
\text { A. the process of education: related to the method of } \\
\text { knowledge and education in materials } \\
\text { B. the resort of the culture of origin: related to the position of } \\
\text { LOCAL cultures in ELT materials }\end{array}$ & $\begin{array}{l}\text { The activity deals with the Ten Commandments, } \\
\text { which express universal values of conduct in } \\
\text { society, associated with the individual duties of the } \\
\text { student in his/her various roles assumed in society. }\end{array}$ \\
\hline $\begin{array}{l}\text { Factors related to teacher } \\
\text { A. the role of the teacher: related to the role that the material } \\
\text { adopts for the teacher } \\
\text { B. Teacher's expectations: related to the supposed expectations } \\
\text { that the teacher takes to the classroom when using the } \\
\text { materials }\end{array}$ & $\begin{array}{l}\text { Activity involving the student's education for } \\
\text { citizenship seeking to raise awareness about } \\
\text { issues such as autonomy, citizenship and values } \\
\text { to transform themselves and their surroundings. } \\
\text { The activity is expected to foster the exercise of } \\
\text { citizenship on the part of each student. }\end{array}$ \\
\hline $\begin{array}{l}\text { Factors related to the learner } \\
\text { A. the role of the student: related to the role that the material } \\
\text { adopts for the student } \\
\text { B. expectations of the learner: related to the alleged } \\
\text { expectations that the student takes to the room when } \\
\text { using the materials }\end{array}$ & $\begin{array}{l}\text { The activity refers the student to the course book } \\
\text { acquired by the institution, based on the selection } \\
\text { of the most relevant content for his/her education } \\
\text { and respecting their demand for artistic activities } \\
\text { and inserted in their reality. }\end{array}$ \\
\hline
\end{tabular}




\title{
2. Criteria for the presence of $\mathrm{CL}$
}

I. “(...) A philosophy or approach to education that considers how education can empower individuals with the tools to understand and criticize the world, aiming to promote social justice" (JORGE, 2012, p. 10).

II. “(...) Teachers begin to see students as individuals in their entirety, (...) begin to recognize (...) what students bring to classes and how what students bring is and is not valued, recognized and approached in the curriculum, in the classroom and in the school environment" (HAWKINS, 2011, p. 107).

III. “(...) In CL, readers see beyond the situation to examine it in a more complex way. Reading from a critical perspective requires readers to analyze and evaluate texts (...), significantly read and question their origin and purpose, and act through the representation of alternative perspectives" (McLAUGHLIN; DeVOOGD, 2004 , p. 23).

It is hoped that from this activity the students understand their various social roles and their attributions within each role, in order to use universal values of love, respect and solidarity in their daily lives.

With the proposed activity, students will have the autonomy to define the most important assignments of each social group they belong to within a specific social role, in addition to creating a space for them to express themselves individually about the values that they prioritize.

The activity is anchored on a reading about inventions in favor of everyday life, followed by a discussion about the role of individualism in perpetuating social inequality. This discussion, followed by the reading of the Ten Commandments, will foster the student's reflexivity about his responsibility in the process of transforming his reality.

\section{Principles for the presence of critical literacy (McLAUGHLIN; DeVOOGD, 2004, p. 17-18)}

Understanding the text to obtain different perspectives

The readings related to the activity allow different points of view on individual values that act directly in the collective.

Analysis of multiple viewpoints in a text, whether they are explicitly represented or not

In addition to individual values, the readings enable reflections on social inequalities, the role of individualism in society and initiatives to change the status quo

Focus on socio-political issues, in order to think about the power relations between individuals

The activity focuses on power relations, the role of individualism in perpetuating social inequalities over the years and the need for individual values applicable to the collectivity.

Action and promotion of social justice through reflexivity and attitudes that foster changes in the inequalities that permeate our society

From the readings, the students will reflect on the role of individualism in the perpetuation of social inequality, about their responsibility in the process of transforming their reality and about their empowerment as a tool for such transformation.

Source: Caetano, 2017.

\author{
Below there is an example of what students have produced in this \\ activity. $^{4}$
}

${ }^{4}$ The activity is described and shown in more detail in Caetano (2017). 
FIGURE 2 - Mini-project 2 - Sample

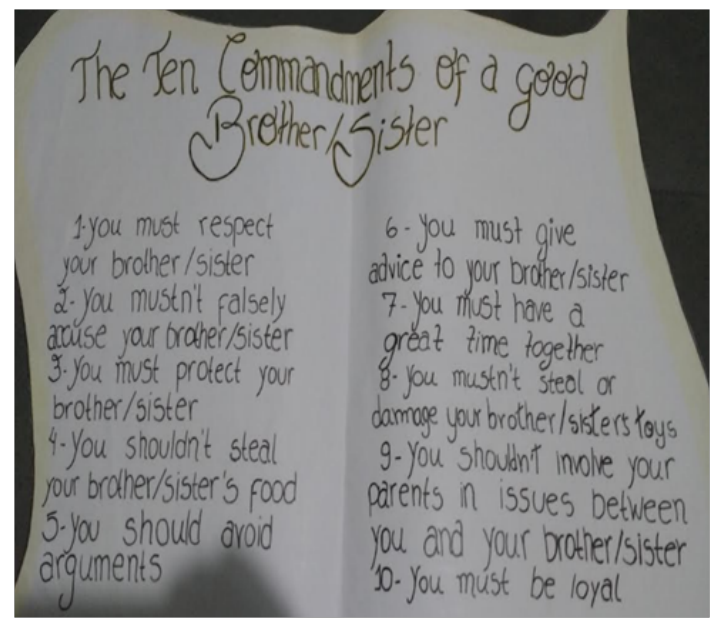

It is possible to observe that the set of principles for the presence of CL was fundamental for the development of the activities proposed. Evidence regarding the impact of these activities on the agency ${ }^{5}$ and empowerment of students is consistently present in the research discussed in Soares (2014) and Caetano (2017). The perspective of CL fomented by the principles was also an instrument for fostering engagement and interest in the discipline, as well as constituting a means for the consolidation of linguistic goals - this was stated in the research findings. Last, but not least, the principles helped me as a researcher and a teacher to acknowledge the value of building up knowledge collaboratively and the power of relationships in the process of teaching and learning.

\section{Final considerations}

This paper aimed to show a set of principles developed for the design of activities for English classes at regular schools in Brazil based on the theories of CL. To this end, a theoretical basis was presented on the relationship between CL and foreign language teaching, as well as a comparative analysis between CL and competing terms. Finally, the last

\footnotetext{
5 Agency is hereby understood as the capacity to socially engage and transform one's reality through critical reflection.
} 
section presented two practical examples of the application of the principles proposed to the process of designing critically grounded activities for EFL settings.

It is hoped that the present study may guide fellow educators in their practical and theoretical investigations by associating the theories of CL with their own teaching environments. It is also expected that this small step can contribute to the pedagogical practice of these professionals, who may, using their context-based experiences, adapt the principles and activities to their own reality.

\section{References}

BRAZIL. Orientações Curriculares para o Ensino Médio. Brasilia: Ministério da Educação. Secretaria de Educação Básica, 2006.

BROWN, G. Cultural values: the interpretation of discourse. ELT Journal, Oxford, v. 44, n. 1, p. 11-17, 1 jun. 1989.

CAETANO, E. A. Letramentos criticos e o uso da língua alvo no ensino de língua inglesa: um olhar autoetnográfico. 2017. 279f. Tese (Doutorado em Estudos Linguísticos) Universidade Federal de Minas Gerais, Belo Horizonte, 2017.

CANAGARAJAH, S. Reclaiming the Local in Language Policy and Practice. New Jersey: Lawrence Erlbaum, 2005. DOI: https://doi.org/10.4324/9781410611840

CARMO, A. R. Reflecting on the Changes that Have Occurred in Society Over the Past Five Years. 2010. Available from: http://www.artigonal.com/educacao-artigos/ refletindo-as-mudancas-ocorridas-na-sociedade-nos-ultimos-cinco-anos-2991298. html. Access on: Jun. 23, 2011.

DUBOC, A. P. M. The Question of the Assessment of English Language Learning According to the Theories of Literacy. 2007. 181f. Dissertação (Mestrado em Estudos Linguísticos e Literários em Inglês) - Universidade de São Paulo, 2007. DOI: 10.11606/D.8.2007.tde-06112007-102340. Available from: http://www.teses. usp.br/teses/disponiveis/8/8147/tde-06112007-102340/pt-br.php. Access on: 06 Jul. 2011.

HALL, J. K. (Re)creating our Worlds with Words: A Sociohistorical Perspective of Face-to-Face Interaction. ELT Journal, Oxford, v. 16, n. 2, p. 206-232, 1995. DOI: https://doi.org/10.1093/applin/16.2.206

HARRIS, T. L.; HODGES, R. E. The Literacy Dictionary: The Vocabulary of Reading and Writing. Newark, Delaware: International Reading Association, 1995. 
HAWKINS, M. R. Dialogic Determination: Constructing a Social Justice Discourse in Language Teacher Education. In: HAWKINS, M. R. Social Justice Language Teacher Education. Bristol, UK: Multilingual Matters, 2011. p. 102-123. DOI: https://doi. org/10.21832/9781847694249-008

JORGE, M. L. S. Critical Literacy, Foreign Language Teaching and the Education about Race Relations in Brazil. The Latin Americanist, [S.l.], v. 56, n. 4, p. 79-90, 2012. DOI: https://doi.org/10.1111/j.1557-203X.2012.01178.x

KALANTZIS, M.; COPE, B. On Globalisation and Diversity. Computers and Composition, v. 23, n. 4, p. 402-411, 2006. DOI: HTTPS://doi.org.10.1016/j. compcom.2006.09.002

KUBOTA, R. Critical Multiculturalism and Second Language Education. In: NORTON, B.; TOOHEY, C. (ed.). Critical Pedagogies and Language Learning. Cambridge: Cambridge University Press, 2004. p. 30-52. DOI: https://doi. org/10.1017/CBO9781139524834.003

KUMARAVADIVELU, B. The Postmethod Condition: (E)merging Strategies for Second/Foreign Language Teaching. TESOL Quarterly, [S.l.], v. 28, n. 1, p. 27-48, 1994. DOI: https://doi.org/10.2307/3587197

KUMARAVADIVELU, B. Critical Classroom Discourse Analysis. TESOL Quarterly, [S.l.], v. 33, n. 3, p. 453-484, 1999. DOI: https://doi.org/10.2307/3587674

KUMARAVADIVELU, B. Beyond Methods: Macrostrategies for Language Teaching. New Heaven: Yale University Press, 2002.

KUMARAVADIVELU, B. The Linguistics Applied in the Era of Globalization. In: LOPES, L. P. M. (org). Por uma Linguística Aplicada indisciplinar. São Paulo: Parabola Editorial, 2006. p. 129-147.

KUMARAVADIVELU, B. Language Teacher Education for a Global Society. New York: Routledge, 2011. DOI: https://doi.org/10.4324/9780203832530

LARSEN-FREEMAN, D.; ANDERSON, M. Techniques and Principles in Language Teaching. Oxford: Oxford University Press, 2011.

LEWISON, M.; FLINT, A. S.; VAN SLUYS, K. Taking on Critical Literacy: The Journey of Newcomers and Novices. Language Art, v. 79, n. 5, p. 382-392, 2002.

McLAUGHLIN, M.; DeVOOGD, G. Critical Literacy: Enhancing Students' Comprehension of Text. New York: Scholastic, 2004.

MATTOS, A. M. A. Education for Citizenship: Introducing Critical Literacy in the EFL Classroom. In: GILLIES, R. M. (Ed.). Pedagogy: New Developments in the Learning Sciences. New York: Nova Science Publishers, 2012. p. 191-212. 
MATTOS, A. M. A. Ensino de inglês como lingua estrangeira na escola pública: letramentos, globalização e cidadania. Jundiaí: Paco Editorial, 2015.

McLAUGHLiN, M.; DeVOOGD, G. Critical Literacy: Enhancing Students' Comprehension of Text. New York: Scholastic, 2004.

NORTON, B.; TOOHEY, K. Critical Pedagogies and Language Learning: An Introduction. In: (ed.). Critical pedagogies and language learning. Cambridge: Cambridge University Press, 2004. p. 1-17. DOI: https://doi.org/10.1017/ CBO9781139524834

OKAZAKI, T. Critical Consciousness and Critical Language Teaching. Second Language Studies, Honolulu, v. 23, n. 2, p. 174-202, 2005.

PENNYCOOK, A. The Concept of Method, Interested Knowledge, and the Politics of Language Teaching. TESOL Quarterly, [S.l.], v. 23, n. 4, p. 589-618, 1989. DOI: https://doi.org/10.2307/3587534

RASHIDI, N. A Model for EFL Materials Development Within the Framework of Critical Pedagogy (CP). English Language Teaching, Ontario, v. 4, n. 2, p. 250-259, 2011. DOI: https://doi.org/10.5539/elt.v4n2p250

RICHARDS, J. C. Curriculum Development in Language Teaching. Cambridge: Cambridge University Press, 2001. DOI: https://doi.org/10.1017/CBO9780511667220

RICHARDS, J. C.; RODGERS, T. S. Approaches and Methods in Language Teaching. Cambridge: Cambridge University Press, 2001. DOI: https://doi.org/10.1017/ CBO9780511667305

RINVOLUCRI, M. The UK, EFLese sub-culture and dialect. Folio, Washington, DC., v. 5, n. 2. p. 12-14, 1999.

SOARES, E. A. C. O letramento crítico no ensino de língua inglesa: identidades, práticas e percepções na formação do aluno-cidadão. 2012. 204f. Dissertação (Mestrado Linguística Aplicada) - Universidade Federal de Minas Gerais, Belo Horizonte, 2012.

SOARES, M. Letramento: um tema em três gêneros. Belo Horizonte: Autêntica, 2009.

VALERIO, K. M.; MATTOS, A. M. A. Critical Literacy and Communicative Teaching: Gaps and Intersections. Revista Brasileira de Linguistica Aplicada, Belo Horizonte, v. 18, n. 2, p. 313-338, 2018. DOI: http://dx.doi.org/10.1590/19846398201812252

WIDDOWS, S.; VOLLER, P. PANSI: A Survey of the ELT Needs of Japanese University Students. Cross Currents, [S.l.], v. 18, n. 2, p. 127-141, 1991.

Data de submissão: 02/08/2019. Data de aprovação: 20/05/2020. 